\title{
Cost analysis in reverse logistics of grade 2 asparagus
}

\section{Análisis de costos en la logística inversa del esparrago de grado 2}

\author{
QUINTERO-RAMÍREZ, Juan Manuel†* \\ Cathedra, Consejo Nacional de Ciencia y Tecnología, Mexico City, Mexico.
}

ID 1 $1^{\text {st }}$ Author: Juan Manuel, Quintero-Ramírez / ORC ID: 0000-0002-1040-2690, CVU CONACYT ID: 292056

DOI: $10.35429 / \mathrm{JM} .2020 .6 .4 .31 .37$

Received January 20, 2020; Accepted June 2020, 2020

\begin{abstract}
This investigation makes observations in the reception of raw material, warehouse and production, to define the percentage of scrap or waste that is had. It is intended to solve these losses, since the percentage of waste adds up to $10 \%$, financially affecting the volume of production of finished product and the costs of farmers who supply said raw material. The objective is to propose an economic valuation of grade 2 asparagus, which helps to reduce monetary losses for farmers and increase profits for the collecting company. Delivery quantities of five asparagus producers are recorded during the months of May to July that supplies the collector who selects and packs the final product. With cost analysis, a comparison is made of values such as incoming kilograms, kilograms usable for export, prices at which farmers are paid and the price at which it is intended to sell in the local market in addition to presenting monetary amounts of recovery to the apply reverse logistics in the company. The result obtained represents the loss of asparagus and a proposal for use is proposed to be sold and how much it would contribute per season when implementing this proposal.
\end{abstract}

Asparagus, Cost analysis, Reverse logistics

\begin{abstract}
Resumen
Esta investigación realiza observaciones en la recepción de materia prima, almacén y producción, para definir el porcentaje de scrap o desechos que se tienen. Se pretende dar solución a estas pérdidas, pues el porcentaje de desperdicio suma $10 \%$, afectando financieramente el volumen de producción de producto terminado y los costos de agricultores que surten dicha materia prima. El objetivo es proponer una valoración económica al esparrago de grado 2, que apoye a reducir las pérdidas monetarias a los agricultores y aumente las ganancias a la empresa acopiadora. Se registran cantidades de entrega de cinco productores de espárragos durante los meses de mayo a julio que abastece a la acopiadora quien selecciona y empaca el producto final. Con análisis de costos, se realiza una comparación de los valores como los kilogramos entrantes, los kilogramos aprovechables para exportación, precios en que se paga a los agricultores y precio al cual se pretende vender en el mercado local además de presentar cantidades monetarias de recuperación al aplicar la logística inversa en la empresa. El resultado obtenido representa la merma del espárrago y se propone una propuesta de utilización para ser vendido y cuanto aportaría por temporada al implementar esta propuesta.
\end{abstract}

Esparrago, Análisis de costos, Logística inversa

Citation: QUINTERO-RAMÍREZ, Juan Manuel. Cost analysis in reverse logistics of grade 2 asparagus. RINOE JournalMicroeconomics. 2020. 4-6:31-37.

\footnotetext{
* Correspondence to Author (Email: quintauro82@gmail.com)

$\uparrow$ Researcher contributing first author.
} 


\section{Introduction}

The constant search to position itself within the preference of customers, has led large corporations in the food sector not only to develop new market strategies and variety in their products, but also to innovate in techniques for quality processes, manufacturing and reverse logistics to achieve an advantage over their competitors, many of whom have taken advantage of this opportunity for knowledge that has permeated towards them and through an internal application of these techniques have been able to solidify their positions in the market.

Day by day, companies generate large amounts of waste in their production processes (equipment and machinery, supplies and raw materials, work, time, capacity and knowledge of human resources, etc.) due to inadequate control of these and the lack of a well-defined, implemented and executed operating method.

One of the ways in which companies lose competitiveness and productivity is due to the waste generated by the quality of the raw material presented by each of the farmers who supply the company with asparagus in order to satisfy the demand of the international market, affecting directly the financial situation of the organizations.

The food industry has been from its birth one of the main economic pillars of the world, due to this the farmers are in search of new products and likewise of the fertility of the farmland causing a rotation of the products the asparagus is discovered and the benefits regarding a cost-benefit capturing the attention of farmers due to its great resistance to both high and low temperatures, the durability of the vegetable and the price in the international market.

Guanajuato, one of the 5 main producers of said product in the Mexican Republic (SAGARPA, 2017), bringing with it the creation of companies of this same nationality dedicated to the processing of this product.
This research is developed within an asparagus production and collection company and seeks to offer dialogue and a beneficial proposal for both the company and the farmers, taking advantage of grade 2 asparagus, which is one that does not meet the physical quality required for export this impacting the financial indicators of each of these.

\section{Selection of asparagus}

The idea arose through observation in the production lines, in which the asparagus that does not meet the international qualitative properties required by customers is removed, this product is discarded for the consumption of farm animals, therefore it is not obtained no monetary value of it.

Focusing on the area of the asparagus process which includes from when it is washed, it is selected by quality, size selection, cutting process, the packaging process and cooling process until the product distribution process, how it is made. Strategies for the sale and distribution of each one of the presentations, as well as the preparation and growth of the personnel that works within the company, solidifying the market so that the brands for which the company works can enter different parts of the world based on the history of hygiene and zero bioterrorism in the products that are made.

The problem that is generated within the company is the inadequate way of disposing of the waste generated by not obtaining the quality required by the company's foreign clients, that is, there is no good reverse logistics that is beneficial for it.

To begin the process, the raw material is received, samples are taken from each of the tables of the associated ranches from which the raw material comes, said samples are $3.6 \mathrm{~kg}$ per table in which the percentage of sludge is reviewed, leg, flowery, crooked / misshapen, scarred, insect damage, mechanical damage, rot, slush, dehydrated, less than $8 \mathrm{~mm}$, cut 8 ", less than 8 ", fungus, rust; in order to obtain the usable percentage of each batch that arrives at the factory and that is used for production. 
This is due to the fact that quality of appearance is required by the foreign client, within said parameters that are established for the quality of asparagus determined under certain international food standards.

Finishing this process of reception and sampling of raw material, the selection of product continues, for example those that are curved, flowered or that for some reason suffered damage and no longer have what is the head of the asparagus, these are separated and continued with its elimination from the company, without taking into account how much this waste represents monetarily per day, per week or per month and without thinking that these can still be used by Mexican consumers and in the monetary amount it represents are these waste that at being sold in other establishments such as restaurants, local vendors, or retail distributors such as the surrounding supply centers can make a profit and instead of just representing a waste or loss, they could represent an extra income of money for the company.

For these wastes, there is no control and as stated by the general management of the company, what is not measured is not improved. This has a strong impact on the profit of the company considering that each kilogram of asparagus has an average cost of $\$ 1.5$ dollars.

The difference that exists in the different measures and qualities in the reception of asparagus from the different producers, causes the classification to be determined at the time of selecting, which entails having second-hand asparagus, which, in turn, use it as food for livestock and that it can be for human consumption, since it carries the required safety but not the necessary measure and specifications to be exported.

By identifying the problem as secondhand asparagus and knowing that this has a beneficial use for both the company and the farmer and for the Mexican market, an analysis is carried out to determine how much money can be recovered from this waste from its sale in the local market for human consumption.
When carrying out reverse logistics, it is possible to see how much income can be returned from the sale of this product that can still be consumed by humans and that determines an additional income towards the company; so, it is understood that, according to Cabeza (2012):
"Reverse logistics encompasses the set of logistics activities for the collection, disassembly and dismemberment of already used products or their components, as well as materials of different types and nature, with the aim of maximizing the use of their value, in the broad sense of their sustainable use and, ultimately, its destruction".

- $\quad$ "Reuse or resale: It consists of recovering the product to give it a new use, since it maintains its shape and has little or no deterioration. In this case, the product is subjected to cleaning and maintenance operations that allow it to be fully utilized, although there are minimal differences from similar but new products".

While the Food and Agriculture Organization of the United Nations (FAO, 2007), determines that: "Asparagus grade 2 or category 2: This category includes shoots that cannot be classified in the higher categories, but meet the minimum requirements specified. Compared to category 1, the shoots may not be as well formed and more curved, their tips are slightly split. Traces of soy stains caused by nonpathogens are allowed and can be removed by the consumer through normal peeling. Green asparagus must be green for at least $60 \%$ of its length. The shoots may be slightly fibrous. The cut at the base of the shoots may be slightly oblique".

Another important concept indicated by Juran (1967) is: "Scrap: This indicator measures the amount of non-conforming product that cannot be recovered, reworked or repaired to bring it to normal conditions of sale. This type of product is considered a waste and directly impacts the cost of poor quality". 


\section{Materials and methods}

To carry out this research, the data was taken and analyzed in 2017, when the authorization and approach with the collecting company was obtained; as well as having information on the 5 producers with the highest harvest in the region in Guanajuato who supply the collector, which allowed data processing.

The research is based on the asparagus packaging area, which consists of 4 lines and these in turn have different areas such as: washing area, selection 1 (quality), selection 2 (size: Extra jumbo or colossal jumbo, extra large, large, standard, small and extra small).

Observations are made on the asparagus packaging line in order to know the entire production process within the company that is carried out to export quality products, as well as observations that lead to the determination of the quality of the grade 2 product to evaluate the differences between the asparagus of first and the asparagus of second and in this way to determine the properties that differentiate them and if it is usable for export.

The next step is to establish the variables that serve to identify a series of data, these were taken daily within the harvest period that goes from May to July, which are:

\section{- $\quad$ Kilograms of incoming asparagus.}

- $\quad$ Kilograms of asparagus usable for export.

- Kilograms of second-rate asparagus.

- $\quad$ Kilograms of asparagus leg that is cut.

With the acquisition of data according to the determined variables, they were captured day by day for approximately 3 months.

In addition to the aforementioned, periodic tours were made to each section of the line to observe the development of the process and identify areas for improvement; for the analysis of the data, the support of office packages was used in which the Microsoft Excel tool to capture the data day by day. With the information structured in the spreadsheet, the data analysis is obtained that determines the competitiveness of said organization around the loss of asparagus.
Finally, with the analysis and processing of the data, the research results were obtained.

The fundamental objective of a check of the volume of asparagus that enters a day corresponds to establish what percentage is usable for the international market, how much waste exists and how much product is for grade 2; this requires a strategic acquisition of data, theoretical application, movement of resources and even economic investments. Therefore, it is worth considering a number of conditions that limit the scope of a swing of the so-called grade 2 stud.

From the results of the analysis that was carried out, the incoming quantities of fresh asparagus, asparagus usable for export, asparagus trimmed leg and asparagus that is discarded because it does not meet quality requirements (grade 2 asparagus) were obtained, the prices with which farmers are paid, the average price with which it is intended to enter the local market, in order to reach the total amount of profit that could be obtained if the company applies the project.

When obtaining the kilograms of asparagus that arrive daily at the company, a comparison was continued, of each half of the month, as well as showing the percentages of product that is used for export, percentage that is removed from the asparagus and based on to that, how much percentage is grade 2 for the local market.

It began by taking the daily incoming kilograms to the company through a format that counts them, in which it is filled in by sections, each of the farmers who supply the company with the product are mentioned, it also has a section that represents each day of the month that is being observed, in order to have control of the kilograms that each farmer brings to the company daily, the total kilograms per supplier during the 15-day period and from this information to be able to obtain a total of total daily kilograms and a total of kilograms per 15day period.

This format is very useful to carry out the research since it was used for filling during the research months, from the second half of May, which is when the asparagus harvest begins, and until the end of the first half of July, which is when it ends. 
From the information obtained, it is captured in other formats where certain information is emptied, such as the total number of incoming kilograms to the company and within the packaging area, information such as the amount of product that can be exported is obtained, the product that is considered as scrap or garbage and from this the amount of cut leg of the raw material (asparagus) and the amount of grade 2 asparagus are obtained, from this the product percentages are obtained.

From this last format, the quantities of incoming product to the company, the quantity of usable product for export, the quantity of leg cut from the raw material (asparagus), as well as the quantity of grade 2 asparagus are established, and the calculate the monetary value invested for the payment of raw material according to kilograms.

In this way, the usable kilograms for export are also obtained by calculating the total amount that is invested to pay farmers for the supply of raw material, paying per kilogram average of $\$ 1.50$ dollars, continuing with the kilograms of grade 2 asparagus with a sale price in the local market of $\$ 0.5$ dollars and thus obtain a total profit for this product.

\section{Results}

The time of the procedure that was carried out to obtain the information was per fortnight from the second of May to the first of July (4 fortnights-2 months), which is when the asparagus production in this area of Guanajuato is highest and carry out exports.

In the collection center, every fortnight data was taken from the kilograms of the different producers and they were captured in each of the established formats, which allowed a control of the quantities that were entered, how much was accepted for export and how much amount was rejected as scrap, in order to make the production payments and how much waste was collected; leaving the results of those kilograms as:
- For the second half of May, the total amount received was 205,436.16 kilograms (from only four producers), of which $75 \%$ was destined for export and of the remaining 51,359.04 kilograms, 26\% was leg waste, and $74 \% \quad(38,005.69$ kilograms) is grade 2 with the opportunity to sell to the local market.

- $\quad$ The sum of asparagus collected in the first half of June with five producers was 396,209.89 kilograms from five suppliers, resulting in 293,195.32 kilograms (74\%) for export and with 75,279.88 kilograms (19\%) of grade 2 and with $7 \%$ that of leg cut (27,734.69 kilograms).

- $\quad$ In the second half of June, 368,620.08 kilograms were collected from the five producers, which with $20 \%(73,724.02$ kilograms) were grade 2, 269,092.66 kilograms $(73 \%)$, it was destined for export and 25,803.41 kilograms (7\%) was leg cut from the asparagus.

- In the first half of July it represented $300,930.18$ kilograms in total, which $70 \%$ was destined for export $(210,651.13$ kilograms) and for grade 2 and short leg it represented $15 \%$ in each one $(45,139.50$ kilograms), supplied by the five producers of the region.

- Throughout this harvest and supply season of the five main producers of asparagus in Guanajuato, 1,271.20 tons of this product were added, which was processed in the collecting company

From the totality of asparagus received, in table 1 , the summary of the quantities received is shown to later be broken down the quantities for grade 2 asparagus, which represents $18.26 \%$ of the total received; while, for asparagus leg it represents $8.81 \%$ of the total. The amount that was exported represented the total, $72.92 \%$, while $27.08 \%$ is non-exportable quantity.

\begin{tabular}{|l|c|c|r|}
\hline \multicolumn{1}{|c}{} & \multicolumn{1}{c}{$\begin{array}{c}\text { Export } \\
\text { quantity }\end{array}$} & \multicolumn{1}{c|}{$\begin{array}{c}\text { Grade 2 asparagus } \\
\text { quantity }\end{array}$} & $\begin{array}{c}\text { Asparagus leg } \\
\text { quantity }\end{array}$ \\
\hline 2nd half May & $154,077.12$ & $38,005.69$ & $13,353.35$ \\
\hline 1st half June & $293,195.31$ & $75,279.88$ & $27,734.69$ \\
\hline $\begin{array}{l}\text { 2nd half of } \\
\text { June }\end{array}$ & $269,092.66$ & $73,724.02$ & $25,803.41$ \\
\hline $\begin{array}{l}\text { 1st half of } \\
\text { July }\end{array}$ & $210,651.13$ & $45,139.50$ & $45,139.50$ \\
\hline Total & $927,016.22$ & $232,149.11$ & $112,030.97$ \\
\hline
\end{tabular}

Table 1 Summary of asparagus quantities and their distribution

Source: Own elaboration with processed data, 2017 
Towards the year of 2017, which is when the information was obtained to calculate the sale prices of asparagus, being for export of $\$$ 1.50 dollars and the payment for grade 2 of $\$$ 0.50 dollars, which Table 2 shows the prices that they recovered for the sale, being 1,390 thousand dollars the payment to the five producers and 116 thousand dollars, which is estimated to be recovered if grade 2 asparagus were sold in the local market, since its use is suitable for human consumption.

\begin{tabular}{|l|r|r|}
\hline & $\begin{array}{c}\text { Payment to } \\
\text { suppliers } \\
\text { (Dlls) }\end{array}$ & $\begin{array}{c}\text { Recovery in } \\
\text { grade 2 } \\
\text { (Dlls) }\end{array}$ \\
\hline 2nd half May & $231,115.68$ & $19,002.84$ \\
\hline 1st half June & $439,792.98$ & $37,639.94$ \\
\hline 2nd half of June & $403,638.99$ & $36,862.01$ \\
\hline 1st half of July & $315,976.69$ & $22,569.76$ \\
\hline Total & $1 ’ 390,524.33$ & $116,074.56$ \\
\hline
\end{tabular}

Table 2 Economic summary of the sale of asparagus and its distribution

Source: Own elaboration with processed data, 2017

\section{Conclusions}

Within the cost analysis carried out, it is concluded that the implementation of the research will be feasible to increase the profits of the company without investing in extra labor to enhance the sale of second-hand asparagus in the national market, since it will be to a concessionaire which will have the product to be able to sell it and deliver the respective profits from the sale of the asparagus, adding more profits to the collecting company.

For the internal process in the company it is observed that more importance should be given in the selection area since it is the one that has the greatest loss within the company.

Key points were identified in the losses in raw material and a proposal is offered to reduce the waste generated by the company's raw material, one of the key proposals is: the implementation of the sale of grade 2 asparagus in the wand centrals within the cities near the factory such as Celaya, Salamanca, Irapuato and Silao, as well as the sale in different restaurants in the cities mentioned above.

The proposal presented results in an impact of its main financial indicators, reducing the loss of asparagus by $8.81 \%$ when it is sold for use in animal feeding processes and not thrown away without using it or as compost.
It is expected that, with these indicators, the company will have greater training for the handling of asparagus, from its harvest to comply with export standards.

With this research, it is concluded that it is convenient to sell grade 2 asparagus for human consumption at the national level, since it does not present any change in flavor or nutrients compared to the premium asparagus that is marketed and exported, as the only the disappointment of the product is due to its size, color or straightness of the asparagus stick, which does not lose anything to sell it locally.

With the application of reverse logistics to grade 2 asparagus, it is extremely attractive, since it will generate $116,074.56$ dollars in the months of production, contributing to the recovery of the investment, it should be well defined that the monetary recovery does not imply any risk for the company since the demand for the vegetable to be marketed at the national level is high and the price is high.

In addition to these conclusions, there are the following recommendations:

- The application and execution of this research, from a financial point of view, does not represent any investment risk. In its different sections, the reasons that predict its success are duly supported and analyzed.

- At the same time, having different marketing strategies that do not imply very high costs, but on the contrary, that encourage the entry of greater income.

The suggestion of the sale of grade 2 asparagus in the supply centers promotes greater and faster marketing, likewise, keeping in mind different marketing strategies that make the service more attractive and that do not imply very high costs but on the contrary that it encourages the entry of higher income. 
Another area of opportunity is to support the farmer who supplies the company with raw material, since by reducing the waste, the external farmer can be supported with a percentage of what is recovered by carrying out social work which benefits to both parties, since with the percentage assigned to farmers they will be able to make different investments with the money obtained from the sale of this product.

\section{References}

Alvarez Botello, J., Morales Mondragón, J. L., \& Hernández Martínez, R. (2013). La logística inversa como estrategia competitiva. Capítulo de libro titulado Retos en la formación de profesionales logísticos: servicio y competitividad. Ed. UAEM.

Asociación Española para la Calidad (AEC). (2015). Retrieved from Asociación Española para la Calidad (AEC): http://www.aec.es/web/guest/centroconocimiento/calidad-total

Bejarano, W. (1992). Manual del espárrago. Quito, Ecuador: Proexant.

Cabeza, Domingo (2012). Logística inversa en la gestión de la Cadena de Suministro. Primera Edición. Ed. Marge Books. Barcelona, España.

CODEX STAN 225. (201). Norma para el espárrago.

González A, M. I., \& Del Pozo L, A. (1999). Cultivo del espárrago. Cillán, Chile: INIA QUILAMAPU.

NORMA PARA EL ESPÁRRAGO. (2001). CODEX STAN 225.

Organización mundial de la Salud, \& Organización de las Naciones Unidas Para la Agricultura. (2007). Codex Alimentarius. Frutas y Hortalizas. Roma.

Pleguezuelos, T. (1999). aiteco.com. Retrieved from aiteco.com: http://www.aiteco.com/quees-un-diagrama-de-flujo/
Secretaria de agricultura, ganadería, desarrollo rural, pesca y alimentación (SAGARPA). (30 de ENERO de 2017). Retrieved from $\mathrm{http} / / / \mathrm{www}$.sagarpa.gob.mx/Delegaciones/quere taro/boletines/2017/enero/Documents/2017b01 1.PDF. 